\title{
Analysis of Covid-19 Impact on Stock's Abnormal Return in Sub Cigarette Sector Companies Listed on BEI
}

\author{
May Mulyaningsih $^{1 *}$, Sri Hartini ${ }^{1}$, Resta Anggraeni ${ }^{2}$, Denis Putra Mahendra ${ }^{1}$
}

${ }^{1}$ May Mulyaningsih,

Pakuan University, Bogor, 16143, INDONESIA

${ }^{2}$ Resta Anggraeni,

PT Gizi Indonesia, Bogor, 16720, INDONESIA

*Corresponding Author

DOI: https://doi.org/10.30880/jstard.2021.03.01.010

Received 3 March 2021; Accepted 16 May 2021; Available online 15 June 2021

\begin{abstract}
Covid-19 is an international pandemic that has paralyzed the national economic sector. This study aims to analyze the impact of Covid-19 on stock's abnormal return in cigarette sub sector companies listed on the Indonesia Stock Exchange in the January to May 2020 period. The population of this study is 5 cigarette sub sector companies listed on the Indonesia Stock Exchange in 2020. The research sample selection uses census method so as to obtain 5 sample companies with an observation period of 5 months (January to May 2020). Secondary data in this study regarding stock's abnormal returns with actual return and market return proxies. Data obtained from the company's daily stock price and composite stock price index. Descriptive statistical analysis, data normality test analysis and hypothesis test analysis are processed using SPSS 25. Statistical test with paired sample t test showed no significant difference in abnormal return between the period of 52 days before and when WFH with a significant level of $95 \%(\alpha=0.05)$. From the SPSS test results it is known that the significance value obtained is equal to 0.911 . When compared with the significance value that has been set. The value is greater $(\alpha>0.05)$. So H1 which states there are differences in stock's abnormal returns before and during the WFH Covid-19 is rejected.
\end{abstract}

Keywords: Covid-19, WFH, stock's abnormal return

\section{Introduction}

\subsection{Problem Identification}

PT H. M. Sampoerna Tbk closed its cigarette factory in Surabaya Rungkut 2 Factory from April 27, 2020 until a later date, in response to the spread of the COVID-19 pandemic in the region. This decision was taken so that the company could carry out thorough cleaning and sanitation so that the spread of COVID-19 could be stopped. This management step was taken after the Task Force for the Acceleration of Handling COVID-19 in East Java Province discovered a new cluster of positive Corona patients in the Rungkut 2 cigarette factory area and 2 Sampoerna employees have died (Thomas, 2020).

During January-March 2020, the issuer coded PT Bentoel Internasional Investama Tbk shares only posted sales of Rp 4.27 trillion. This realization was down 15.24\% compared to company's sales in the same period the previous year which reached Rp 5.04 trillion. After selling less cost of goods sold and other expenses, company recorded a loss for the year that can be distributed to the parent entity or net loss of Rp 43.29 billion (Julian, 2020).

PT Indonesian Tobacco Tbk has postponed plans to expand markets to a number of regions this year. This decision was made based on consideration of conditions in the field amid the corona pandemic situation (covid-19). Previously the company had planned to expand its market reach by exploring new markets such as Ambon and the surrounding islands, Ternate and Tobelo. Marketing activities to a number of these areas are currently difficult because the mobility of the company's marketing team is constrained by a number of factors such as the implementation of Large-Scale Social 
Restrictions (PSBB) in several regions. The company chose to focus its sales on the existing target market that had been worked on previously (Saksono, 2020).

To break the chain of distribution of Covid-19 and carry out social distancing, PT Gudang Garam Tbk decided to stop production from 1 May 2020 to 27 May 2020. Secretary of Gudang Garam Company, Heru Budiman said that the plant termination also coincided with joint leave before Idul Fitri 2020. Every year we implement a joint leave policy twice for all employees, the first before Idul Fitri and the second before Christmas/ New Year. In general, the period of each joint leave lasts for two weeks. The production that should have been done in May had been diverted in the previous months in accordance with the plan so that the implementation of the Joint Leave did not disrupt the production process. The company ensures the availability of ready-to-sell goods on the market will continue to be fulfilled as long as the company implements Joint Leave ahead of Idul Fitri 2020, and it is hoped that the company's performance will not be disrupted by the Joint Leave policy (Nurfitriani, 2020).

\subsection{Problem Formulation}

Problem formulation for this research is how the impact of Covid 19 on stock's abnormal return in cigarette sub sector companies listed on the Indonesia Stock Exchange in the January-May 2020 period (5 months).

\subsection{Research Objectives}

This research aims to analyze the impact of Covid-19 on stock's abnormal return in cigarette sub sector companies listed on the Indonesia Stock Exchange in the January-May 2020 period (5 months).

\subsection{Research Implication}

\subsubsection{Academic Implication}

This research is expected to add knowledge about the problem under study. This research also expected as a reference material in conducting further research. Further this research is expected to contribute the development of accounting in general and financial accounting in particular.

\subsubsection{Practical Implication}

(1) This research is expected for the companies to know the performance of their shares in maximizing the value of the company. This research also expected to help the company's management in problems solving and decision making. (2) Further this research is expected to be material for investor consideration in investments making and investment decisions in the capital market.

\section{Illustrations}

\subsection{Literature Review}

\subsubsection{Work from Home (WFH) Covid-19}

World Health Organization (WHO) (2020) define that Corona virus is a group of viruses that can cause disease in humans and animals. Humans usually cause respiratory infections, from the common cold to serious illnesses such as Middle East Respiratory Syndrome (MERS) and Severe Acute Respiratory Syndrome (SARS). A new type of coronavirus found in humans since an extraordinary event appeared in Wuhan China, in December 2019, later named Severe Acute Respiratory Syndrome Coronavirus 2 (SARS-COV2), and caused Coronavirus Disease-2019 (COVID19).

Common symptoms include $38^{\circ} \mathrm{C}$ fever, dry cough, and shortness of breath. If there are people who within 14 days before the symptoms appear have traveled to an infected country, or have treated/ had close contact with a COVID-19 sufferer, then that person will have further laboratory tests to confirm the diagnosis (Kemenkes, 2020). Responding to the growing situation and information related to the spread of Covid-19, the Ministry of Finance has adopted various related policies, including issuing circular letters containing WFH policies for Ministry of Finance employees. The Office began to carry out WFH from March 19, 2020, alternately in accordance with the criteria stated in the Ministry of Finance Circular Letter No. 5 year 2020 (Dewayani, 2020).

According to Jokowi, one way that needs to be done so that the handling of Covid-19 can be done more optimally is to start reducing activities outside the home. "It's time we work from home, learn from home, worship at home." Jokowi said in a press conference at Bogor Palace at March 15, 2020. There are advantages and disadvantages to this concept of WFH. But most companies still offer this WFH to their employees and this has become a new trend today especially when there is an outbreak like the corona virus outbreak (Ratriani, 2020).

There are many advantages of WFH (Ratriani, 2020) such as: (1) There are more job applicants for certain jobs with certain people who have obstacles. Like the location of the house far from the workplace or workers with disabilities. In addition, parents who have children can still work without leaving their children; (2) There is more balance between personal life and the world of work. Many people claim that a calmer or warmer atmosphere is found at home that helps 
concentrate on work so they can get the assigned work done quickly; (3) There are many savings due to office infrastructure costs such as space, electricity bills, etc; (4) Employees feel motivated because they get a good work-life balance, and increase their productivity. There are also disadvantages from WFH (Ratriani, 2020) such as: (1) Can cause problems related to monitoring work; (2) Technology infrastructure costs needed to implement the concept at home; (3) Security problems can arise with data being transferred and which cannot be monitored easily; (4) Not all jobs are suitable for work with the concept of WFH. Sometimes communication problems between employees can also make a job problematic.

\subsection{Problem Formulation}

\subsubsection{Stock's Abnormal Return}

Market reaction is indicated by changes in prices of the relevant securities, this reaction can be measured using abnormal returns. If using an abnormal return, it is said that an announcement containing information will provide an abnormal return to the market, otherwise that does not contain information does not provide an abnormal return to the market. Abnormal return is the excess of the actual return of the normal return. The normal return is the expected return by investors. Thus abnormal return is the difference between the actual return that occurs with the expected return. It can be said that an abnormal return occurs if the actual return is higher than the expected profit (Jogiyanto, 2016).

Abnormal returns occur because there is new information or new events that change the company's value and reaction, by investors in the form of an increase or decrease in stock prices. This study using the market adjusted model with the consideration that this model is considered sufficient to describe market expectations in general. By using a market-adjusted model. The best estimator for estimating the return of a security is the market index return at that time (Jogiyanto, 2016). So the magnitude of the abnormal return is determined by the formula:

$A R_{i t}=R_{i t}-R_{m t}$

Explanation:

ARit $=$ Stock abnormal return $\mathrm{i}$ in day $\mathrm{t}$

Rit $=$ Stock actual return $\mathrm{i}$ in day $\mathrm{t}$

$\mathrm{Rmt}=$ Market return in day $\mathrm{t}-1$

Stock returns are profits expected by an investor in the future of a number of funds that have been placed. Hope describes something that can happen outside of what is expected (Fahmi, 2013:152). Two sources of stock returns are Capital Gain (accrual return) and Yield Zubir (2011:4). Factors that influence stock returns are micro factors and macro factors (Samsul, 2015:200). Micro factors are the factors from inside the company such as financial ratios. Macro factors are the factors from outside the company such as economic condition and politic condition.

There are two types of stock returns (Jogiyanto, 2016):

1. Actual return that is a return which has occurred.

$$
R_{i t}=\frac{P_{i t}-P_{i t-1}}{P_{i t-1}}
$$

Explanation:

Rit $=$ Stock's actual return $\mathrm{i}$ in day $\mathrm{t}$

Pit $=$ Stock's price $\mathrm{i}$ in day $\mathrm{t}$

Pit-1 = Stock's price $\mathrm{i}$ in day $\mathrm{t}-1$

2. Expected return that is return which is expected to be obtained by investors in the future.

$$
E\left(R_{i t}\right)=
$$

Explanation:

$\mathrm{E}($ Rit $)=$ Expected stocks' profit level in day $\mathrm{t}$

$\mathrm{Rmt}=$ Market profit level on period $\mathrm{t}$ (market return) 
$\mathrm{R}_{\mathrm{mt}}=\frac{\mathrm{IHSG}_{\mathrm{t}}-\mathrm{IHSG}_{\mathrm{t}-1}}{\mathrm{IHSG} \mathrm{H}_{\mathrm{t}-1}}$

Explanation:

Rmt $=$ Market return

IHSGt = Indeks Harga Saham Gabungan or Composite Stock Price Index on day t

IHSGt-1 = Indeks Harga Saham Gabungan or Composite Stock Price Index on day t-1

The stock price is the price on the real market, and is the most easily determined price because it is the price of a stock in the ongoing market or if the market is closed, then the market price is the closing price (Azis dkk, 2015:80). Factors that affecting stock prices can come from internal and external factors of the company (Zulfikar, 2016:91-93). Internal factors such as financing announcements, management board of director announcements, investment announcements. External factors such as legal announcements, securities announcements, politic condition.

\subsection{Previous Research}

Dependent variables in this research using stock's abnormal returns which has similarities with the research of Puspita (2012); Septiani and Akbar (2014); Khoirullah (2015); Suherman, Nuraisyah and Ahmad (2016); also Achsan (2016). This research has differences with the research of Sihombing and Kamal (2016); Dianah, Situmorang and Iryani (2017); Resmilia, Hardiyanto and Ilmiyono (2018); also Normalita (2018) in the form of dependent variables that use financial performance.

\subsection{Conceptual Framework}

Testing the information content is intended to see the reaction of an announcement. If the announcement contains information, the market is expected to react when the announcement is received by the market. The market reaction is indicated by a change in the price of the security in question where this reaction can be measured by abnormal return (Jogiyanto, 2016). Abnormal return is obtained by comparing the expected level of profit (market return) with actual return. If the actual return is higher than the expected profit level. it can be said that an abnormal return occurs. This research using the ratio of abnormal stock returns that are proxied by Actual Return (Rit) and Expected Return E (Rit) using the market adjusted model. This is supported by the research of Septiani and Akbar (2014); Achsan (2016); Suherman, Nuraisyah and Ahmad (2016); also Normalita (2018).

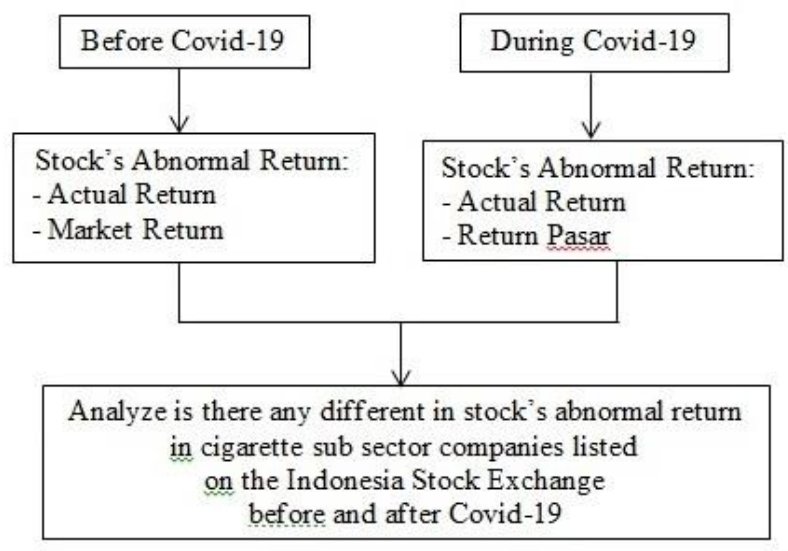

Fig. 1 - Research constellation

\subsection{Hypothesis}

Based on the problem formulation, research objectives, literature review, previous research and conceptual framework then the hypotheses is:

H1 : There are differences in stock's abnormal returns before and during the WFH Covid-19.

\section{Research Methods}

\subsection{Types of Research}

This type of research used in this study is descriptive research. This research will analyze the impact of the Covid19 announcement on stock's abnormal returns in cigarette sub sector companies listed on the Indonesia Stock Exchange in the January-May 2020 period (5 months). While the research technique used in this study is quantitative statistics. 


\subsubsection{Normality Test}

To detect the normality of the data, it is necessary to do a normality test using either the distribution curve in the form of a normal curve and the normal plot or using the Kolmogorov Smirnov test, with decision making criteria that if significance at $>0.05$ means the data is normally distributed and if the significance is $<0.05$ then the data not normally distributed according to Priyatno (2014).

\subsubsection{Hypothesis Test}

To find out whether the parameters of the two populations are different or not, the statistical test used is called the two mean difference test. Generally, the approach taken can be by the $\mathrm{Z}$ distribution ( $\mathrm{Z}$ test) or the $\mathrm{t}$ distribution ( $\mathrm{t}$ test). $\mathrm{Z}$ test can be used if (1) the population standard deviation $(\sigma)$ is known, and (2) the sample size is large (>30). If the two conditions are not met, the type of test used is the two sample t-test. Based on the relationship between populations, the $\mathrm{t}$ test can be classified into two types of tests, namely dependent sample t-test and independent sample t-test.

\section{Research Result}

\subsection{Data Collection Results}

Secondary data in this study regarding stock's abnormal returns with actual return and market return proxies. Data obtained from the company's daily stock price and composite stock price index. Then notification and announcement date of acquisition of each company for January-May 2020 (5 months) obtained from the official website of the Indonesia Stock Exchange (IDX) which are www.idx.co.id and www.duniainvest.com.

\subsubsection{Actual Return Data in Cigarette Sub Sector Companies 52 Days Before and During Work from Home (WFH) Covid-19 Announcement}

According to Jogiyanto (2016), the definition of actual return or return is the return that has occurred. Realized returns are calculated using historical data. Realized returns are important because they are used as a measure of the company's performance. Realized return or historical return is also useful as a basis for determining expected returns and future risks. Based on the analysis and calculation of data on 5 cigarette sub sector companies listed on the Indonesia Stock Exchange in 2020 for 52 days before and 52 days during Work From Home (WFH) Covid-19 obtained the value of the actual return.

Data in Appendix 1 show that the actual return value during the observation period that is 52 days before and 52 days during WFH. PT Bentoel Internasional Investama Tbk has an average value of actual return before WFH that is equal to 0.0009 and the average actual return during WFH is 0.0045 shows a positive reaction by showing an increase of 0.0036 in the WFH period. This indicates that the information content of WFH is quickly absorbed by the market, so as to provide a great opportunity to obtain a higher actual return. For negative reactions the actual return is also shown by several companies such as PT Gudang Garam Tbk which has an average value of actual returns before WFH that is equal to 0.0062 and the average actual return during WFH becomes -0.0044. Likewise with PT H. M. Sampoerna Tbk. PT Indonesia Tobacco Tbk and PT Wismilak Inti Makmur Tbk which shows the decrease value in the actual return in the WFH period.

\subsubsection{Market Return Data in Cigarette Sub Sector Companies 52 Days Before and During Work from Home (WFH) Covid-19 Announcement}

According to Jogiyanto (2016), the definition of expected return is the return that is expected to be obtained by investors in the future. This return is used for investment decision making. This return is more important than the historical return (realized) because this return is expected by all investors in the future. Data in Appendix 2 show that the average value of market returns during the observation period that is 52 days before and 52 days when WFH. From the 5 cigarette sub sector companies listed in Indonesia Stock Exchange in 2020, the average value of market returns decreased when they did WFH. This is because one of the ballast sentiments of stock movements is the investor response to the increase in positive cases of corona virus in a number of countries. This can make the state government slow down or even cancel the reopening of economic activity. The existence of this epidemic caused all 9 sectors in the IHSG move negatively, driven by various industry sectors which fell $1.44 \%$ and followed by the trade sector with a weakening of $1.42 \%$ (Nugroho, 2020).

\subsection{Data Analysis}

The data used in this study are stock returns and market returns for 52 days before and 52 days during Work From Home (WFH), consisting of 5 cigarette sub sector companies listed on the Indonesia Stock Exchange in 2020. The data is in the form of stock returns and market returns which can be used to determine the impact of these variables on stock's abnormal returns. Testing the analysis of the impact of WFH on stock's abnormal returns on cigarette sub sector 
companies listed on the Indonesia Stock Exchange in 2020 is carried out by statistical testing. This research uses SPSS 25 software. The method used is descriptive statistical analysis relating to the application of statistical methods to collect, process, present and analyze quantitative data. The Normality test and the Hypothesis test are conducted in testing the analysis. Testing data must be normally distributed so that test results can meet predetermined requirements, normality shows test results that are probability values $>0.05$ means that data is normally distributed, so that it is used by the author to be used as data in conducting all statistical tests.

\subsubsection{Descriptive Statistical Analysis}

This research data has been processed using SPSS 25. Following are the results of descriptive statistical analysis for this study with an abnormal return ratio. Abnormal return is the advantage of the actual return to normal returns. Abnormal returns will occur if the announcement of the acquisition has information content and an efficient capital market, stock prices and returns react with the announcement of the acquisition so that by utilizing public information. the company can benefit above normal. Descriptive statistical data in the form of abnormal returns during the 52 days before and 52 days during WFH can be seen below.

\section{Table 2 - Descriptive statistics 52 days before and 52 days during WFH}

\begin{tabular}{|l|c|c|r|r|r|}
\hline \multicolumn{7}{|c|}{ Descriptive Statistics } \\
\hline & N & Minimum & Maximum & Mean & Std. Deviation \\
\hline $\begin{array}{l}\text { Stock's Abnomal Retum } \\
\text { 52 Days Before WFH }\end{array}$ & 5 & -.0048 & .0061 & .000700 & .0041719 \\
\hline $\begin{array}{l}\text { Stock's Abnormal Retum } \\
52 \text { Days During WFH }\end{array}$ & 5 & -.0055 & .0065 & .000200 & .0054295 \\
\hline Valid N (listwise) & 5 & & & & \\
\hline
\end{tabular}

Based on table above it is known that the number of samples used in this study were 5 companies with a period of 52 days before and 52 days during $\mathrm{WFH}$ sso that $\mathrm{N}=5$. Furthermore, the descriptive statistical results before and after the WFH Covid-19 announcement in the table above will be explained as follows:

(1) The average value of abnormal return for 52 days before WFH is 0.000700 with a standard deviation of 0.0041719 . The large standard deviation indicates a very large variation or a large gap between the maximum and minimum values. The average value of the abnormal return of 0.000700 indicates that in general the shareholders of the company gained prosperity (positive abnormal return) in the period before WFH, while each maximum and minimum value of the abnormal return variable was 0.0061 and -0.0048 .

(2) The average value of abnormal return for 52 days during WFH is 0.000200 with a standard deviation of 0.005429. The large standard deviation indicates a very large variation or a significant gap between the maximum and minimum values. The average value of the abnormal return of 0.000200 shows that in general the company's shareholders gain an increase in prosperity (positive abnormal return) in the period during WFH, while each maximum and minimum value of the abnormal return variable is equal to 0.0065 and -0.0055 .

\subsubsection{Data Normality Test Analysis}

To determine the appropriate statistical test tool for the hypothesis made, the data normality test is first performed using the Kolmogorov-Smirnov Test with a probability of 5\%. The purpose of the normality test is used to determine the distribution of data in variables that will be used in normal distribution research or not. To detect normality in the research data, this was carried out using Kolmogorov-Smirnov (K-S Test). The criteria used are if significance $(\alpha<5 \%)$ then the data is not normally distributed, and vice versa (Ghozali, 2016).

Table 3 - One-Sample Kolmogorov-Smirnov test

\begin{tabular}{|c|c|c|c|}
\hline \multicolumn{4}{|c|}{ One-Sample Kolmogorov-Smirnov Test } \\
\hline & & $\begin{array}{c}\text { Stock's Abnormal Return } \\
52 \text { Days Before WFH }\end{array}$ & $\begin{array}{l}\text { Stock's Abnormal Return } \\
52 \text { Days During WFH }\end{array}$ \\
\hline \multicolumn{2}{|l|}{$\mathrm{N}$} & 5 & 5 \\
\hline \multirow[t]{2}{*}{ Normal Parameters } & Mean & .000700 & .000200 \\
\hline & Std. Deviation & .0041719 & .0054295 \\
\hline \multirow[t]{3}{*}{ Most Extreme Differences } & Absolute & .119 & .284 \\
\hline & Positive & .119 & .284 \\
\hline & Negative & -117 & .236 \\
\hline \multicolumn{2}{|l|}{ Test Statistic } & .119 & .284 \\
\hline \multicolumn{2}{|l|}{ Asymp, Sig. (2-tailed) } & $200^{\circ \mathrm{A}}$ & $200^{\mathrm{CA}}$ \\
\hline
\end{tabular}


Based on the normality test results for abnormal return 52 days before WFH shows a value of 0.119 with a probability of 0.200 which is greater than 0.05 , so it can be concluded that data 52 days before WFH is normally distributed. Likewise with the Kolmogorov-Smirnov test for stock's abnormal return 52 days during WFH shows a value of 0.284 with a probability of 0.200 which is greater than 0.05 , so it can be concluded that 52 days data during WFH is normally distributed. On the basis of the results of this test, it can be concluded that the data are normally distributed. Therefore the most suitable difference test used for hypothesis testing on these variables is the parametric test, namely paired sample t-test.

\subsubsection{Hypothesis Test Analysis}

Based on the results of the normality test, the data used in this study are normally distributed. Therefore as previously explained that if the data are normally distributed, then the most suitable test tool used to test the hypothesis in this study is paired sample ttest, $t$ is paired, and vice versa for data that is not normally distributed. Then the most appropriate difference test used is the non parametic test, the Wilcoxon Signed Rank test. Hypothesis testing in this study aims to answer the question whether or not there is a difference in stock's abnormal return before and during WFH. In testing hypotheses using a paired sample t-test. the basis for decision making is that if the significance value obtained $>$ from the specified level of significance then $\mathrm{H} 1$ which states there are differences in stock's abnormal returns before and during the WFH Covid-19 is rejected, and if the significance value obtained < of the specified level of significance then H1 is accepted, with the level of significance specified is 5\%. Following are the results of hypothesis testing using paired sample t-tests.

Table 4 - Paired samples t-test

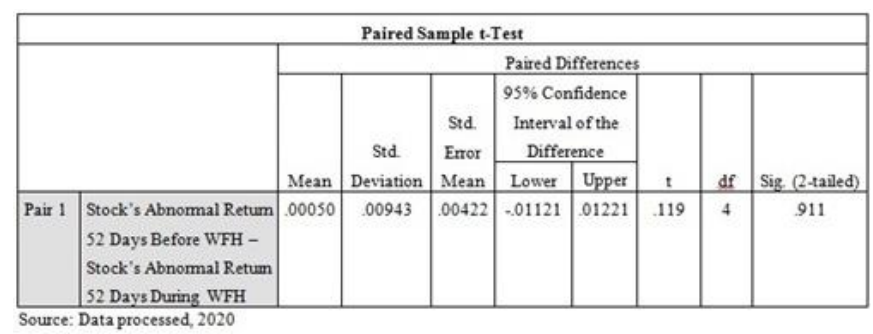

Table above shows the results of paired sample t-test analysis on stock's abnormal returns. In testing 52 days before and 52 during WFH obtained a significance value of 0.911 with a calculated value of 0.119 . Then obtained a significant value of $0.911(\alpha>0.05)$, this means that there is no significant difference in the impact of abnormal returns on shares before and during work from home, thus the research hypothesis is rejected.

\subsection{Discussion}

After testing the data normality for the variables used in this study, it is known that the stock's abnormal returns used in this study are normally distributed. Because the data are normally distributed, the different test used to test the hypothesis is the paired sample t-test. Based on the results of the paired sample ttest in Table 4, on the abnormal return test 52 days before and during WFH shows a significance value of 0.911 , it shows that the significance value obtained is greater than the specified level of significance $(0.911>0.05)$ means that there is no significant difference in abnormal return between 52 days before and 52 days during.

According to Jogiyanto (2016), normal return is the expected return or return expected by investors. The average normal return reacts negatively from the 5 companies experiencing a decrease in the average value of market returns when doing WFH. This is because one of the ballast sentiments of stock movements is the investor response to the increase in positive cases of corona virus in a number of countries. This can make the state government slow down or even cancel the reopening of economic activity. The existence of this epidemic caused all 9 sectors in the IHSG to move negatively, driven by various industry sectors which fell $1.44 \%$ and followed by the trade sector with a weakening of $1.42 \%$ (Nugroho, 2020).

When compared to the annual average so far around $10 \%$, the percentage increase is significant at $23 \%$. Retail Selling Price (RSP) is also the case because the annual increase is the highest of $23 \%$ this year reaching $35 \%$. When viewed per cigarette factory, the increase in RSP of PT Gudang Garam Tbk (GGRM), PT H. M. Sampoerna Tbk (HMSP) and PT Bentoel Internasional Investama Tbk (RMBA) were subject to a 52\% increase in RSP. This far exceeds the burden of other factories 42\%-43\% such as PT Wismilak Inti Makmur (WIIM). The year 2020 is a severe challenge for cigarette issuers due to a $23 \%$ increase in tariffs and a $35 \%$ average RSP.

The annual average increase in excise tax rates is in the range of $10 \%$ and RSP at $23 \%$. Twice the increase in excise tax rates and RSP will create a new equilibrium in the cigarette market and also in the future. Significant or even unaffected impacts will be a reference for future policies (Kartodiwiryo, 2020). The share price of listed sectors of the 
cigarette sector last year was depressed due to the cigarette tax which has risen again. So that the impact on decreasing stock's abnormal returns.

\section{Conclusions and Implications}

\subsection{Conclusions}

Based on the results of the analysis and discussion, it can be concluded that the Work from Home (WFH) Covid-19 has not yet fully produced the results expected. From observations for 52 days before and when WFH, there were no significant differences in investor reactions related to WFH. The existence of this epidemic Covid-19 causes all 9 sectors in the IHSG to move negatively. This is because one of the ballast sentiments of stock movements is the investor response to the increase in positive cases of corona virus in a number of countries. This can make the state government slow down or even cancel the reopening of economic activity. So the impact caused doesn't have a significant effect on stock's abnormal returns. Statistical test with paired sample t test showed no significant difference in abnormal return between the period of 52 days before and when WFH with a significant level of $95 \%(\alpha=0.05)$. From the SPSS test results it is known that the significance value obtained is equal to 0.911 . When compared with the significance value that has been set. the value is greater $(\alpha>0.05)$. So H1 which states there are differences in stock's abnormal returns before and during the WFH Covid-19 is rejected.

\subsection{Implications}

\subsubsection{Academic Implication}

For further research, it is expected to add other variables such as the acquisition value and the size of the target company that can be used to influence the impact of company stock's abnormal returns before and during Work from Home Covid-19. In addition it is necessary to add more samples from others sub sectors companies, those companies which listed on the Indonesia Stock Exchange and those which are not listed on the Indonesia Stock Exchange.

\subsubsection{Practical Implication}

(1) For company management needs to make preparations including looking at the condition of the company, both in terms of company management and company financials. In addition, it is also necessary for company management to look at national and international economic conditions whether in good or bad conditions for companies. (2) For investors and potential investors who want to invest in a public company, it should be more careful in responding to every activity and event that occurs. Companies with high liquidity tend to be safer in times of crisis than less liquid ones. Liquidity is the company's ability to meet its shortterm obligations (debt). Investors and potential investors should invest in stocks with the best liquidity.

\section{Appendix A: Actual Return Value in Cigarette Sub Sector Companies Listed on the Indonesia Stock Exchange in 2020, 52 Days Before and 52 During Work From Home (WFH)}

\begin{tabular}{cccccc}
\hline Day Number & \multicolumn{7}{c}{ Issuer } & PT Gudang \\
\cline { 2 - 6 } & Garam Tbk & $\begin{array}{c}\text { Pampoerna } \\
\text { Tbk }\end{array}$ & $\begin{array}{c}\text { PT Indonesia } \\
\text { Tobacco Tbk }\end{array}$ & $\begin{array}{c}\text { PT Bentoel } \\
\text { Internasional } \\
\text { Investama Tbk }\end{array}$ & $\begin{array}{c}\text { PT Wismilak } \\
\text { Inti Makmur } \\
\text { Tbk }\end{array}$ \\
\hline-52 & $(0.0139)$ & $(0.0234)$ & $(0.0709)$ & 0.0000 & 0.0000 \\
\hline-51 & $(0.0051)$ & $(0.0047)$ & $(0.0193)$ & 0.0000 & $(0.0119)$ \\
\hline-50 & $(0.0290)$ & $(0.0444)$ & 0.0237 & $(0.0063)$ & $(0.0667)$ \\
\hline-49 & $(0.0244)$ & $(0.0088)$ & $(0.0307)$ & 0.0192 & 0.0000 \\
\hline-48 & 0.0035 & $(0.1950)$ & 0.0116 & 0.0000 & 0.0112 \\
\hline-47 & $(0.0155)$ & 0.2423 & $(0.0039)$ & 0.0000 & 0.0349 \\
\hline-46 & $(0.0039)$ & $(0.0216)$ & 0.0360 & $(0.0250)$ & $(0.0058)$ \\
\hline-45 & 0.0000 & 0.0043 & $(0.0385)$ & 0.0000 & 0.0237 \\
\hline-43 & 0.0069 & 0.0176 & $(0.0076)$ & 0.0127 & $(0.0059)$ \\
\hline-42 & $(0.0017)$ & 0.0134 & $(0.0076)$ & 0.0000 & 0.0180 \\
\hline-41 & $(0.0047)$ & 0.0000 & $(0.0038)$ & 0.0000 & 0.0000 \\
\hline
\end{tabular}




\begin{tabular}{|c|c|c|c|c|c|}
\hline-40 & 0.0171 & 0.0139 & 0.0316 & 0.0000 & $(0.0118)$ \\
\hline-39 & $(0.0057)$ & 0.0000 & $(0.0232)$ & 0.0464 & 0.0833 \\
\hline-38 & $(0.0104)$ & $(0.0046)$ & $(0.0189)$ & 0.0000 & 0.0263 \\
\hline-37 & $(0.0060)$ & 0.0046 & 0.0193 & $(0.0066)$ & $(0.0065)$ \\
\hline-36 & 0.0179 & 0.0286 & $(0.0226)$ & $(0.0559)$ & 0.0132 \\
\hline-35 & 0.0106 & $(0.0047)$ & 0.0729 & 0.0000 & 0.0203 \\
\hline-34 & $(0.0022)$ & $(0.0276)$ & 0.0978 & 0.0000 & $(0.0133)$ \\
\hline-33 & 0.0197 & 0.0236 & 0.0766 & 0.0063 & 0.0274 \\
\hline-32 & $(0.0013)$ & 0.0242 & $(0.0500)$ & 0.0667 & 0.0210 \\
\hline-31 & 0.0054 & 0.0049 & $(0.0435)$ & $(0.0066)$ & 0.0362 \\
\hline-30 & $(0.0036)$ & $(0.0048)$ & $(0.0086)$ & 0.0067 & 0.0073 \\
\hline-29 & $(0.0098)$ & 0.0147 & 0.0087 & $(0.0566)$ & $(0.0072)$ \\
\hline-28 & $(0.0136)$ & $(0.0097)$ & $(0.0336)$ & 0.0600 & $(0.0143)$ \\
\hline-27 & 0.0111 & 0.0148 & 0.0128 & $(0.0506)$ & 0.0072 \\
\hline-26 & 0.0121 & 0.0175 & $(0.0486)$ & 0.0533 & 0.0072 \\
\hline-25 & 0.0000 & 0.0025 & $(0.0784)$ & $(0.0385)$ & 0.0073 \\
\hline-24 & 0.0091 & 0.0000 & $(0.0255)$ & 0.0000 & $(0.0072)$ \\
\hline-23 & 0.0000 & 0.0051 & 0.0300 & 0.0065 & $(0.0072)$ \\
\hline-22 & 0.0115 & 0.0051 & $(0.0291)$ & 0.0000 & 0.0221 \\
\hline-21 & $(0.0059)$ & 0.0025 & 0.1957 & 0.0000 & $(0.0145)$ \\
\hline-20 & $(0.0023)$ & 0.0026 & 0.0455 & 0.0000 & $(0.0072)$ \\
\hline-19 & $(0.0032)$ & 0.0026 & 0.0577 & 0.0000 & 0.0072 \\
\hline-18 & $(0.0067)$ & 0.0051 & 0.0146 & 0.0065 & $(0.0143)$ \\
\hline-17 & $(0.0071)$ & 0.0130 & $(0.0284)$ & 0.0000 & 0.0145 \\
\hline-16 & 0.0131 & 0.0079 & 0.0657 & 0.0845 & 0.0147 \\
\hline-15 & 0.0009 & 0.0242 & 0.0366 & 0.0071 & $(0.0073)$ \\
\hline-14 & 0.0036 & 0.0420 & 0.1900 & 0.0000 & 0.0148 \\
\hline-13 & 0.0343 & 0.0318 & $(0.0881)$ & 0.0071 & 0.1157 \\
\hline-12 & 0.0426 & 0.0176 & $(0.0168)$ & 0.0072 & 0.0901 \\
\hline-11 & 0.0303 & 0.0149 & 0.0056 & 0.0000 & $(0.0431)$ \\
\hline-10 & $(0.0251)$ & $(0.0429)$ & $(0.0872)$ & 0.0000 & $(0.0252)$ \\
\hline-9 & $(0.0193)$ & $(0.0196)$ & 0.0428 & 0.0000 & $(0.0403)$ \\
\hline-8 & 0.0162 & 0.0000 & 0.0389 & 0.0859 & 0.0081 \\
\hline-7 & 0.0109 & 0.0408 & 0.0286 & $(0.0303)$ & 0.0250 \\
\hline-6 & 0.1206 & 0.1029 & $(0.0223)$ & 0.0233 & 0.0909 \\
\hline-5 & $(0.0191)$ & $(0.0281)$ & $(0.0529)$ & 0.0157 & $(0.0517)$ \\
\hline-4 & 0.0011 & $(0.0184)$ & $(0.0357)$ & $(0.1241)$ & 0.0642 \\
\hline-3 & 0.0409 & 0.0516 & 0.0235 & $(0.0268)$ & 0.0792 \\
\hline-2 & 0.0577 & 0.0265 & $(0.0425)$ & 0.0000 & 0.0100 \\
\hline-1 & 0.0619 & 0.0747 & $(0.0148)$ & $(0.0387)$ & 0.0753 \\
\hline 0 & 0.0748 & 0.0725 & 0.0305 & 0.0403 & 0.0690 \\
\hline 1 & 0.0311 & 0.0565 & $(0.1992)$ & 0.0000 & 0.0741 \\
\hline 2 & 0.0745 & 0.0736 & $(0.1987)$ & 0.0643 & 0.0519 \\
\hline 3 & $(0.1666)$ & $(0.1413)$ & $(0.1984)$ & 0.0687 & 0.0000 \\
\hline 4 & 0.0749 & 0.0717 & $(0.0304)$ & 0.0000 & 0.0694 \\
\hline 5 & 0.0089 & $(0.0271)$ & $(0.0295)$ & 0.0738 & $(0.0270)$ \\
\hline
\end{tabular}




\begin{tabular}{|c|c|c|c|c|c|}
\hline 6 & $(0.1292)$ & $(0.0883)$ & $(0.0025)$ & 0.0702 & $(0.0633)$ \\
\hline 7 & $(0.0500)$ & $(0.0208)$ & 0.0737 & $(0.0087)$ & $(0.0366)$ \\
\hline 8 & 0.0751 & 0.0396 & 0.0053 & $(0.1481)$ & 0.0513 \\
\hline 9 & $(0.0043)$ & $(0.0246)$ & 0.0356 & 0.0714 & $(0.0127)$ \\
\hline 10 & 0.0262 & 0.0071 & 0.0489 & 0.0000 & $(0.0247)$ \\
\hline 11 & $(0.0893)$ & $(0.0782)$ & 0.0675 & $(0.0935)$ & $(0.1474)$ \\
\hline 12 & $(0.0573)$ & $(0.0436)$ & 0.0516 & 0.0611 & $(0.1204)$ \\
\hline 13 & $(0.0637)$ & $(0.0983)$ & $(0.1842)$ & 0.0480 & $(0.0357)$ \\
\hline 14 & 0.0359 & 0.0440 & $(0.1163)$ & 0.0000 & 0.0370 \\
\hline 15 & 0.0234 & 0.0623 & 0.0750 & 0.0593 & 0.0693 \\
\hline 16 & $(0.0173)$ & $(0.0331)$ & $(0.0123)$ & 0.0631 & $(0.0381)$ \\
\hline 17 & $(0.0159)$ & 0.0091 & 0.0125 & 0.0000 & 0.0194 \\
\hline 18 & 0.0157 & $(0.0266)$ & $(0.0244)$ & $(0.0177)$ & $(0.0096)$ \\
\hline 19 & 0.0053 & 0.0497 & 0.0250 & $(0.1630)$ & 0.0000 \\
\hline 20 & 0.0703 & 0.0321 & 0.0101 & 0.0714 & $(0.0714)$ \\
\hline 21 & $(0.0332)$ & $(0.0459)$ & 0.0000 & 0.0000 & $(0.0968)$ \\
\hline 22 & 0.0314 & 0.0283 & 0.0180 & 0.0500 & 0.0420 \\
\hline 23 & 0.0324 & 0.0127 & 0.0716 & $(0.1045)$ & 0.0625 \\
\hline 24 & $(0.0248)$ & $(0.0032)$ & 0.0708 & 0.0720 & $(0.0261)$ \\
\hline 25 & $(0.0028)$ & 0.0096 & $(0.0231)$ & $(0.0672)$ & 0.0088 \\
\hline 26 & 0.0380 & 0.0263 & 0.0579 & 0.0152 & 0.0459 \\
\hline 27 & $(0.0161)$ & $(0.0098)$ & 0.0547 & $(0.0294)$ & $(0.0091)$ \\
\hline 28 & $(0.0125)$ & 0.0132 & 0.0065 & 0.0000 & $(0.0517)$ \\
\hline 29 & $(0.0211)$ & $(0.0350)$ & 0.0655 & 0.0625 & $(0.1145)$ \\
\hline 30 & $(0.0066)$ & $(0.0157)$ & 0.0545 & 0.0000 & $(0.0576)$ \\
\hline 31 & 0.0295 & 0.0493 & 0.0185 & $(0.0791)$ & 0.0692 \\
\hline 32 & $(0.0118)$ & $(0.0256)$ & 0.0266 & 0.0000 & 0.0656 \\
\hline 33 & 0.0074 & $(0.0459)$ & 0.0735 & 0.0000 & $(0.0758)$ \\
\hline 34 & 0.0034 & $(0.0030)$ & 0.0746 & 0.0000 & 0.0313 \\
\hline 35 & $(0.0189)$ & $(0.0120)$ & $(0.0420)$ & 0.0000 & 0.0159 \\
\hline 36 & $(0.0094)$ & $(0.0178)$ & $(0.0206)$ & 0.0000 & 0.0080 \\
\hline 37 & $(0.0087)$ & $(0.0146)$ & 0.0519 & 0.0072 & 0.0246 \\
\hline 38 & $(0.0424)$ & $(0.0419)$ & 0.0744 & 0.0073 & 0.0517 \\
\hline 39 & $(0.0309)$ & $(0.0350)$ & 0.0750 & 0.0703 & 0.0000 \\
\hline 40 & $(0.0030)$ & $(0.0054)$ & 0.0753 & $(0.0229)$ & 0.0175 \\
\hline 41 & 0.0025 & 0.0163 & $(0.0262)$ & 0.0234 & $(0.0256)$ \\
\hline 42 & 0.0373 & 0.0367 & 0.0552 & 0.0000 & 0.0174 \\
\hline 43 & 0.0005 & $(0.0733)$ & $(0.0597)$ & 0.0667 & 0.0088 \\
\hline 44 & 0.0074 & $(0.0155)$ & $(0.0052)$ & $(0.0400)$ & $(0.0087)$ \\
\hline 45 & $(0.0162)$ & 0.0078 & 0.0157 & 0.0081 & $(0.1727)$ \\
\hline 46 & $(0.0169)$ & $(0.0077)$ & 0.0410 & 0.0508 & 0.0611 \\
\hline 47 & 0.0263 & 0.0515 & $(0.0394)$ & 0.0000 & $(0.0224)$ \\
\hline 48 & $(0.0140)$ & $(0.0027)$ & 0.0270 & $(0.0084)$ & $(0.0219)$ \\
\hline 49 & 0.0021 & 0.0306 & $(0.0054)$ & 0.0000 & 0.0224 \\
\hline 50 & $(0.0067)$ & 0.0000 & $(0.0053)$ & $(0.0083)$ & $(0.0290)$ \\
\hline 51 & $(0.0041)$ & $(0.0164)$ & $(0.0079)$ & $(0.0698)$ & $(0.0483)$ \\
\hline
\end{tabular}




\begin{tabular}{cccccc}
\hline 52 & 0.0047 & 0.0111 & $(0.0026)$ & 0.0078 & 0.0284 \\
\hline $\begin{array}{c}\text { Average } \\
\text { Before WFH }\end{array}$ & 0.0062 & 0.0089 & 0.0044 & 0.0009 & 0.0118 \\
\hline $\begin{array}{c}\text { Average } \\
\text { During WFH }\end{array}$ & -0.0044 & -0.0052 & 0.0035 & 0.0045 & -0.0076 \\
\hline Source: Data processed. 2020 & & & &
\end{tabular}

Appendix B: Market Return Value in Cigarette Sub Sector Companies Listed on the Indonesia Stock Exchange in 2020, 52 Days Before and 52 During Work From Home (WFH)

\begin{tabular}{|c|c|c|c|c|c|}
\hline \multirow[b]{2}{*}{$\begin{array}{c}\text { Day } \\
\text { Number }\end{array}$} & \multicolumn{5}{|c|}{ Issuer } \\
\hline & $\begin{array}{l}\text { PT Gudang } \\
\text { Garam Tbk }\end{array}$ & $\begin{array}{c}\text { PT H.M. } \\
\text { Sampoerna } \\
\text { Tbk } \\
\end{array}$ & $\begin{array}{l}\text { PT Indonesia } \\
\text { Tobacco Tbk }\end{array}$ & $\begin{array}{c}\text { PT Bentoel } \\
\text { Internasional } \\
\text { Investama Tbk }\end{array}$ & $\begin{array}{c}\text { PT Wismilak } \\
\text { Inti Makmur } \\
\text { Tbk } \\
\end{array}$ \\
\hline 52 & $(0.0063)$ & $(0.0063)$ & $(0.0063)$ & $(0.0063)$ & $(0.0063)$ \\
\hline 51 & 0.0106 & 0.0106 & 0.0106 & 0.0106 & 0.0106 \\
\hline 50 & $(0.0035)$ & $(0.0035)$ & $(0.0035)$ & $(0.0035)$ & $(0.0035)$ \\
\hline 49 & 0.0086 & 0.0086 & 0.0086 & 0.0086 & 0.0086 \\
\hline 48 & $(0.0078)$ & $(0.0078)$ & $(0.0078)$ & $(0.0078)$ & $(0.0078)$ \\
\hline 47 & $(0.0001)$ & $(0.0001)$ & $(0.0001)$ & $(0.0001)$ & $(0.0001)$ \\
\hline 46 & $(0.0034)$ & $(0.0034)$ & $(0.0034)$ & $(0.0034)$ & $(0.0034)$ \\
\hline 45 & $(0.0046)$ & $(0.0046)$ & $(0.0046)$ & $(0.0046)$ & $(0.0046)$ \\
\hline 44 & 0.0067 & 0.0067 & 0.0067 & 0.0067 & 0.0067 \\
\hline 43 & $(0.0004)$ & $(0.0004)$ & $(0.0004)$ & $(0.0004)$ & $(0.0004)$ \\
\hline 42 & $(0.0009)$ & $(0.0009)$ & $(0.0009)$ & $(0.0009)$ & $(0.0009)$ \\
\hline 41 & 0.0075 & 0.0075 & 0.0075 & 0.0075 & 0.0075 \\
\hline 40 & 0.0011 & 0.0011 & 0.0011 & 0.0011 & 0.0011 \\
\hline 39 & 0.0008 & 0.0008 & 0.0008 & 0.0008 & 0.0008 \\
\hline 38 & $(0.0025)$ & $(0.0025)$ & $(0.0025)$ & $(0.0025)$ & $(0.0025)$ \\
\hline 37 & 0.0008 & 0.0008 & 0.0008 & 0.0008 & 0.0008 \\
\hline 36 & 0.0181 & 0.0181 & 0.0181 & 0.0181 & 0.0181 \\
\hline 35 & 0.0036 & 0.0036 & 0.0036 & 0.0036 & 0.0036 \\
\hline 34 & $(0.0003)$ & $(0.0003)$ & $(0.0003)$ & $(0.0003)$ & $(0.0003)$ \\
\hline 33 & 0.0092 & 0.0092 & 0.0092 & 0.0092 & 0.0092 \\
\hline 32 & 0.0198 & 0.0198 & 0.0198 & 0.0198 & 0.0198 \\
\hline 31 & 0.0095 & 0.0095 & 0.0095 & 0.0095 & 0.0095 \\
\hline 30 & $(0.0064)$ & $(0.0064)$ & $(0.0064)$ & $(0.0064)$ & $(0.0064)$ \\
\hline 29 & $(0.0094)$ & $(0.0094)$ & $(0.0094)$ & $(0.0094)$ & $(0.0094)$ \\
\hline 28 & $(0.0014)$ & $(0.0014)$ & $(0.0014)$ & $(0.0014)$ & $(0.0014)$ \\
\hline 27 & $(0.0021)$ & $(0.0021)$ & $(0.0021)$ & $(0.0021)$ & $(0.0021)$ \\
\hline 26 & 0.0080 & 0.0080 & 0.0080 & 0.0080 & 0.0080 \\
\hline 25 & $(0.0004)$ & $(0.0004)$ & $(0.0004)$ & $(0.0004)$ & $(0.0004)$ \\
\hline 24 & 0.0070 & 0.0070 & 0.0070 & 0.0070 & 0.0070 \\
\hline 23 & 0.0070 & 0.0070 & 0.0070 & 0.0070 & 0.0070 \\
\hline 22 & 0.0009 & 0.0009 & 0.0009 & 0.0009 & 0.0009 \\
\hline 21 & $(0.0001)$ & $(0.0001)$ & $(0.0001)$ & $(0.0001)$ & $(0.0001)$ \\
\hline 20 & $(0.0033)$ & $(0.0033)$ & $(0.0033)$ & $(0.0033)$ & $(0.0033)$ \\
\hline 19 & $(0.0071)$ & $(0.0071)$ & $(0.0071)$ & $(0.0071)$ & $(0.0071)$ \\
\hline 18 & $(0.0023)$ & $(0.0023)$ & $(0.0023)$ & $(0.0023)$ & $(0.0023)$ \\
\hline
\end{tabular}




\begin{tabular}{|c|c|c|c|c|c|}
\hline 17 & 0.0102 & 0.0102 & 0.0102 & 0.0102 & 0.0102 \\
\hline 16 & 0.0130 & 0.0130 & 0.0130 & 0.0130 & 0.0130 \\
\hline 15 & 0.0034 & 0.0034 & 0.0034 & 0.0034 & 0.0034 \\
\hline 14 & 0.0173 & 0.0173 & 0.0173 & 0.0173 & 0.0173 \\
\hline 13 & 0.0277 & 0.0277 & 0.0277 & 0.0277 & 0.0277 \\
\hline 12 & 0.0152 & 0.0152 & 0.0152 & 0.0152 & 0.0152 \\
\hline 11 & 0.0171 & 0.0171 & 0.0171 & 0.0171 & 0.0171 \\
\hline 10 & $(0.0285)$ & $(0.0285)$ & $(0.0285)$ & $(0.0285)$ & $(0.0285)$ \\
\hline 9 & $(0.0233)$ & $(0.0233)$ & $(0.0233)$ & $(0.0233)$ & $(0.0233)$ \\
\hline 8 & 0.0021 & 0.0021 & 0.0021 & 0.0021 & 0.0021 \\
\hline 7 & 0.0254 & 0.0254 & 0.0254 & 0.0254 & 0.0254 \\
\hline 6 & 0.0704 & 0.0704 & 0.0704 & 0.0704 & 0.0704 \\
\hline 5 & $(0.0161)$ & $(0.0161)$ & $(0.0161)$ & $(0.0161)$ & $(0.0161)$ \\
\hline 4 & 0.0129 & 0.0129 & 0.0129 & 0.0129 & 0.0129 \\
\hline 3 & 0.0528 & 0.0528 & 0.0528 & 0.0528 & 0.0528 \\
\hline 2 & $(0.0024)$ & $(0.0024)$ & $(0.0024)$ & $(0.0024)$ & $(0.0024)$ \\
\hline 1 & 0.0462 & 0.0462 & 0.0462 & 0.0462 & 0.0462 \\
\hline 0 & 0.0525 & 0.0525 & 0.0525 & 0.0525 & 0.0525 \\
\hline 1 & 0.0291 & 0.0291 & 0.0291 & 0.0291 & 0.0291 \\
\hline 2 & 0.0549 & 0.0549 & 0.0549 & 0.0549 & 0.0549 \\
\hline 3 & $(0.0213)$ & $(0.0213)$ & $(0.0213)$ & $(0.0213)$ & $(0.0213)$ \\
\hline 4 & 0.0515 & 0.0515 & 0.0515 & 0.0515 & 0.0515 \\
\hline 5 & 0.0132 & 0.0132 & 0.0132 & 0.0132 & 0.0132 \\
\hline 6 & $(0.0925)$ & $(0.0925)$ & $(0.0925)$ & $(0.0925)$ & $(0.0925)$ \\
\hline 7 & $(0.0455)$ & $(0.0455)$ & $(0.0455)$ & $(0.0455)$ & $(0.0455)$ \\
\hline 8 & 0.0297 & 0.0297 & 0.0297 & 0.0297 & 0.0297 \\
\hline 9 & $(0.0274)$ & $(0.0274)$ & $(0.0274)$ & $(0.0274)$ & $(0.0274)$ \\
\hline 10 & 0.0163 & 0.0163 & 0.0163 & 0.0163 & 0.0163 \\
\hline 11 & $(0.0145)$ & $(0.0145)$ & $(0.0145)$ & $(0.0145)$ & $(0.0145)$ \\
\hline 12 & $(0.0198)$ & $(0.0198)$ & $(0.0198)$ & $(0.0198)$ & $(0.0198)$ \\
\hline 13 & $(0.0392)$ & $(0.0392)$ & $(0.0392)$ & $(0.0392)$ & $(0.0392)$ \\
\hline 14 & 0.0069 & 0.0069 & 0.0069 & 0.0069 & 0.0069 \\
\hline 15 & 0.0328 & 0.0328 & 0.0328 & 0.0328 & 0.0328 \\
\hline 16 & $(0.0048)$ & $(0.0048)$ & $(0.0048)$ & $(0.0048)$ & $(0.0048)$ \\
\hline 17 & 0.0054 & 0.0054 & 0.0054 & 0.0054 & 0.0054 \\
\hline 18 & $(0.0175)$ & $(0.0175)$ & $(0.0175)$ & $(0.0175)$ & $(0.0175)$ \\
\hline 19 & 0.0174 & 0.0174 & 0.0174 & 0.0174 & 0.0174 \\
\hline 20 & 0.0324 & 0.0324 & 0.0324 & 0.0324 & 0.0324 \\
\hline 21 & $(0.0333)$ & $(0.0333)$ & $(0.0333)$ & $(0.0333)$ & $(0.0333)$ \\
\hline 22 & 0.0129 & 0.0129 & 0.0129 & 0.0129 & 0.0129 \\
\hline 23 & 0.0164 & 0.0164 & 0.0164 & 0.0164 & 0.0164 \\
\hline 24 & $(0.0144)$ & $(0.0144)$ & $(0.0144)$ & $(0.0144)$ & $(0.0144)$ \\
\hline 25 & $(0.0057)$ & $(0.0057)$ & $(0.0057)$ & $(0.0057)$ & $(0.0057)$ \\
\hline 26 & 0.0217 & 0.0217 & 0.0217 & 0.0217 & 0.0217 \\
\hline 27 & $(0.0038)$ & $(0.0038)$ & $(0.0038)$ & $(0.0038)$ & $(0.0038)$ \\
\hline 28 & $(0.0036)$ & $(0.0036)$ & $(0.0036)$ & $(0.0036)$ & $(0.0036)$ \\
\hline
\end{tabular}




\begin{tabular}{|c|c|c|c|c|c|}
\hline 29 & $(0.0083)$ & $(0.0083)$ & $(0.0083)$ & $(0.0083)$ & $(0.0083)$ \\
\hline 30 & $(0.0316)$ & $(0.0316)$ & $(0.0316)$ & $(0.0316)$ & $(0.0316)$ \\
\hline 31 & 0.0241 & 0.0241 & 0.0241 & 0.0241 & 0.0241 \\
\hline 32 & $(0.0053)$ & $(0.0053)$ & $(0.0053)$ & $(0.0053)$ & $(0.0053)$ \\
\hline 33 & 0.0046 & 0.0046 & 0.0046 & 0.0046 & 0.0046 \\
\hline 34 & 0.0025 & 0.0025 & 0.0025 & 0.0025 & 0.0025 \\
\hline 35 & $(0.0090)$ & $(0.0090)$ & $(0.0090)$ & $(0.0090)$ & $(0.0090)$ \\
\hline 36 & 0.0110 & 0.0110 & 0.0110 & 0.0110 & 0.0110 \\
\hline 37 & 0.0075 & 0.0075 & 0.0075 & 0.0075 & 0.0075 \\
\hline 38 & 0.0090 & 0.0090 & 0.0090 & 0.0090 & 0.0090 \\
\hline 39 & 0.0014 & 0.0014 & 0.0014 & 0.0014 & 0.0014 \\
\hline 40 & $(0.0008)$ & $(0.0008)$ & $(0.0008)$ & $(0.0008)$ & $(0.0008)$ \\
\hline 41 & $(0.0083)$ & $(0.0083)$ & $(0.0083)$ & $(0.0083)$ & $(0.0083)$ \\
\hline 42 & 0.0006 & 0.0006 & 0.0006 & 0.0006 & 0.0006 \\
\hline 43 & $(0.0175)$ & $(0.0175)$ & $(0.0175)$ & $(0.0175)$ & $(0.0175)$ \\
\hline 44 & $(0.0032)$ & $(0.0032)$ & $(0.0032)$ & $(0.0032)$ & $(0.0032)$ \\
\hline 45 & $(0.0158)$ & $(0.0158)$ & $(0.0158)$ & $(0.0158)$ & $(0.0158)$ \\
\hline 46 & $(0.0079)$ & $(0.0079)$ & $(0.0079)$ & $(0.0079)$ & $(0.0079)$ \\
\hline 47 & $(0.0194)$ & $(0.0194)$ & $(0.0194)$ & $(0.0194)$ & $(0.0194)$ \\
\hline 48 & $(0.0189)$ & $(0.0189)$ & $(0.0189)$ & $(0.0189)$ & $(0.0189)$ \\
\hline 49 & 0.0049 & 0.0049 & 0.0049 & 0.0049 & 0.0049 \\
\hline 50 & $(0.0063)$ & $(0.0063)$ & $(0.0063)$ & $(0.0063)$ & $(0.0063)$ \\
\hline 51 & $(0.0242)$ & $(0.0242)$ & $(0.0242)$ & $(0.0242)$ & $(0.0242)$ \\
\hline 52 & 0.0071 & 0.0071 & 0.0071 & 0.0071 & 0.0071 \\
\hline $\begin{array}{c}\text { Average } \\
\text { Before } \\
\text { WFH } \\
\end{array}$ & 0.0058 & 0.0058 & 0.0058 & 0.0058 & 0.0058 \\
\hline $\begin{array}{c}\text { Average } \\
\text { During } \\
\text { WFH }\end{array}$ & -0.0021 & -0.0021 & -0.0021 & -0.0021 & -0.0021 \\
\hline
\end{tabular}

Source: Data processed. 2020

\section{References}

[1] Achsan, F. (2016). Analisis Pengaruh Merger dan Akuisisi Terhadap Return Saham dan Volume Perdagangan Saham Pada Perusahaan Go Public BEI. Skripsi. Universitas Islam Negeri Alaludin Makasar

[2] Azis dkk. (2015). Manajemen Investasi: Fundamental. Teknikal. Perilaku Investor dan Return Saham. Yogyakarta: Penerbit Deepublish

[3] Dewayani, T. (2020). Bekerja dari Rumah (Work from Home) Dari Sudut Pandang Unit Kepatuhan Internal. djkn.kemenkeu.go.id [online]. Tersedia di https://www.djkn.kemenkeu.go.id/artikel/baca/13014/Bekerja-dariRumah-Work-From-Home-Dari-Sudut-Pandang-UnitKepatuhan-Internal.html. [Diakses 31 Maret 2020]

[4] Dianah, T., Situmorang, M., and Iryani., L. D. (2017). Analisis Dampak Keputusan Akuisisi Terhadap Perubahan Kinerja Keuangan Perusahaan Pengakuisisi (Studi Kasus Pada PT Jasa Marga (Perseroan) Tbk. JIAFE Vol.2 No.2 Agustus 2017

[5] Fahmi, I. (2013). Analisis Laporan Keuangan. Bandung: Penerbit Alfabeta

[6] Jogiyanto, H. (2016). Teori Portofolio dan Analisis Investasi. Edisi Kesepuluh.Yogyakarta: Penerbit BPFE

[7] Julian, M. (2020). Penjualan Bentoel Internasional Investama (RMBA) Turun 15,24\% di Kuartal 12020. KONTAN.CO.ID [online]. Tersedia di https://industri.kontan.co.id/news/penjualan-bentoelinternasionalinvestama-rmba-turun-15,24\%-di-kuartal-1-2020. [Diakses 16 Juni 2020]

[8] Kemenkes. (2020). FAQ - Kementerian Kesehatan Republik Indonesia. kemkes.go.id [online]. Tersedia di https://www.kemkes.go.id/folder/view/full-content/structurefaq.html. [Diakses 4 Juli 2020] 
[9] Khoirullah, A. L. (2015). Analisis Dampak Informasi Akuisisi Terhadap Return Saham Pada Perusahaan Akuisitor yang Diakuisisi (Studi Empiris Pada Perusahaan Akuisitor dan yang Diakuisisi yang Terdaftar di BEI Tahun 20102013). Skripsi. Universitas Jember

[10] Normalita, D. W. (2018). Pengaruh Merger dan Akuisisi Terhadap Kinerja Keuangan dan Kinerja Pasar Pada Perusahaan Yang Terdaftar di Bursa Efek Indonesia. Skripsi. Universitas Islam Indonesia

[11] Nurfitriyani, A. (2020). Astaga, Ternyata Gudang Garam Sudah Berhenti Beroperasi Sejak Awal Mei. wartaekonomi.co.id [online]. Tersedia di https://www.wartaekonomi.co.id/read284651/astagaternyata-gudanggaram-sudah-berhenti-beroperasi-sejakawal-mei. [Diakses 8 Mei 2020].

[12] Puspita, A. (2012). Analisis Dampak Abnormal Return Saham Sebelum dan Sesudah Pengumuman Merger dan Akuisisi Pada Perusahaan yang Terdaftar di Bursa Efek Indonesia Periode 2006-2011. Skripsi. Universitas Sumatera Utara.

[13] Priyatno, D. (2014). Cara Kilat Belajar Analisis Data Dengan SPSS 20. Yogyakarta: Penerbit Mediakom.

[14] Ratriani, V. R. (2020). Jokowi Instruksikan Bekerja dari Rumah, Ini Arti Work from Home. Kompas.com [online]. Tersedia di https://www.kompas.com/tren/read/2020/03/16/195035165/jokowi-instruksikan-bekerja-dari-rumahini-arti-work-fromhome?page=all. [Diakses 16 Maret 2020].

[15] Resmilia, R., Hardiyanto, A. T. and Ilmiyono., A. F. (2018). Pengaruh Merger dan Akuisisi Terhadap Kinerja Keuangan Perusahaan Manufaktur Go Public Yang Terdaftar Di BEI Periode 2012-2014. JIAFE Vol.5 No.5 2018.

[16] Saksono, D. (2020). Akibat Covid-19, Indonesian Tobacco (ITIC) tunda sejumlah rencana ekspansi pasar. indopremier.com [online].Tersedia di https://www.indopremier.com/ipotnews/newsDetail.php?jdl=Akibat_Covid _19_Indonesian_Tobacco_(ITIC)_tunda_sejumlah_rencana_ekspansi_pasar\&news_id=372761\&group_news=R ESEARCHNEWS\&taging_subtype=PG002\&name=\&search=y_general\&q=,\&halaman=1. [Diakses 25 Juli 2020].

[17] Samsul, M. (2015). Pasar Modal dan Manajemen Portofolio. Jakarta: Erlangga.

[18] Septiani, A. D. dan Akbar, L. F. (2014). Pengaruh Merger dan Akuisisi Terhadap Return Perusahaan Yang Bertindak Sebagai Bidder (Studi di Bursa Efek Indonesia Periode 2009-2013). Skripsi. Universitas Indonesia.

[19] Sihombing, N. and Kamal, M. (2016) Analisis Pengaruh Pengumuman Merger dan Akuisisi Terhadap Abnormal Return Saham dan Kinerja Keuangan Perusahaan (Studi pada perusahaan yang melakukan Merger dan Akuisisi pada Tahun 2011 dan Terdaftar di Bursa Efek Indonesia). JOM Volume 5. Nomor 3. Tahun 2016. Halaman 1-15 ISSN (Online): 2337-3792.

[20] Suherman, Nuraisyah, R. and Ahmad, G. N. (2016). Abnormal Return dan Likuiditas Saham Atas Pengumuman Akuisisi. Jurnal Manajemen/Volume XX. No. 01. Februari 2016: 151-168.

[21] Thomas, V. B. (2020). Pekerja Kena Corona, Sampoerna Tutup Pabrik Rokok di Surabaya. tirto.id [online]. Tersedia di https://tirto.id/pekerja-kena-corona-sampoerna-tutuppabrik-rokok-di-surabaya-ffR8. [Diakses 30 April 2020].

[22] WHO. (2020). Pertanyaan Jawaban Terkait COVID-19 Untuk Publik. who.int [online]. Tersedia di https://www.who.int/indonesia/news/novel-coronavirus/qafor-public. [Diakses 4 Juli 2020].

[23] Zubir, Z. (2011). Manajemen portofolio : Penerapannya dalam Investasi Saham. Jakarta: Salemba Empat.

[24] Zulfikar, (2016). Pengantar Pasar Modal Dengan Pendekatan Statistika Edisi Pertama. Cetakan Pertama. Yogyakarta: Penerbit Gramedia. 